AperTO - Archivio Istituzionale Open Access dell'Università di Torino

Children and Young People as Moral and Legal Actors. Findings from Studies Conducted in Northern Italy

This is a pre print version of the following article:

Original Citation:

Availability:

This version is available http://hdl.handle.net/2318/133789

since 2016-04-20T12:27:29Z

Publisher:

Oxford University Press

Terms of use:

Open Access

Anyone can freely access the full text of works made available as "Open Access". Works made available under a Creative Commons license can be used according to the terms and conditions of said license. Use of all other works requires consent of the right holder (author or publisher) if not exempted from copyright protection by the applicable law. 


\title{
13
}

\section{Children and Young People as Moral and Legal Actors: Findings from Studies Conducted in Northern Italy}

\author{
Roberta Bosisio ${ }^{1}$
}

\subsection{Children as moral actors}

Children and childhood were studied for a long time in relation to other subjects and other conceptual fields, such as theories of education, sociology of family and socialization. $^{2}$ This approach arose from the traditional concept of socialization, according to which children are social becomings and not social beings. For this reason children were not autonomous actors and they were not considered in the present tense as children, but as what they would become: adults.

Today, on the contrary, sociologists consider children to be individuals that participate in social life, starting with their specific perspective on the world, and according to models of action that may differ from those of adults. ${ }^{3}$ They are no longer seen as passive recipients of the teachings of adults, but rather as actors who play an active role in their own development. Therefore, children, together with adults, participate in the construction of the social world that surrounds them, of childhood itself and of the interpretative reproduction of their shared culture. ${ }^{4}$

\footnotetext{
1 Roberta Bosisio is $\mathrm{PhD}$ in Sociology of Law, she worked as research fellow in Sociology of Law at the University of Milan (Italy) where she cooperates with the Department of Social and Political Studies. Her main fields of study and research regard sociology of childhood and children's rights. She is interested in studying young people's lives from their point of views and voices.

Among her publications: 'Children's Right to Be Heard: What Children Think' (International Journal of Children's Rights, 19/2011),Bambini e agire morale. Rappresentazioni delle norme e dei diritti nell'infanzia e nell'adolescenza (Milano, 2010); " "Right" and "not right”. Representations of Justice in Young People', (Childhood, 2/2008); Non è giusto! Dilemmi morali e rappresentazioni della giustizia nelle rappresentazioni degli adolescenti (with Roberto Cammarata \& Persio Tincani-edited by Paola Ronfani, Roma 2007); 'La percezione dei diritti nell'infanzia e nell'adolescenza. Una ricerca empirica' (Sociologia del diritto, 1/2005); Quello che ci spetta. I diritti fondamentali nelle rappresentazioni degli adolescenti (with Luisa Leonini \& Paola Ronfani, Roma 2003).

2 William Corsaro, The Sociology of Childhood (Thousand Oaks, 1997); Heinz Hengst, Helga Zehier (eds.), Per una sociologia dell'infanzia (Milano, 2004); Chris Jenks, 'Introduction: constituting the child', in Id. (ed.), The Sociology of Childhood: Essential Readings (London, 1982), 9-24.

3 Allison James, Chris Jenks, Alan Prout, Theorizing Childhood (London, 1998).

${ }^{4}$ William Corsaro, The Sociology of Childhood (Thousand Oaks, 1997); Alan Prout, Allison James, 'Introduction', in Id. (eds.), Constructing and Reconstructing Childhood (London, 1990), 1; Jens Qvortrup, Childhood as a Social Phenomenon. An Introduction to a Series of National Reports, Eurosocial Report, 36 (Vienna, 1991).
} 
According to the new sociology of childhood, children also possess moral reasoning skills. As a matter of fact, it is noticeable that children, starting from their early years, are continuously faced with issues of justice and fairness in their everyday interactions, as well as with decision-making situations that carry moral implications. ${ }^{5}$ For this reason, according to scholars, from a very early age they develop a good practical knowledge of moral concepts. However, adults usually do not recognize children as moral actors. ${ }^{6}$

The results of many studies show children's competence in terms of moral reasoning and action, and also their awareness of the discrepancy between their moral competence and the low moral status attributed to them by adults. ${ }^{7}$ These findings confirm that teenagers internalize a developmental model of moral growth and that the low social position attributed by adults to them also influences children's selfimage. $^{8}$

\subsection{Survey findings}

We will present some examples drawn from the findings of three studies ${ }^{9}$ on normative and legal socialization, which show that young people possess high moral and legal reasoning skills.

The first one was carried out in 2001-2002 among students attending the last year of lower secondary school in four schools in Milan and in two schools in two small towns in the north-west of Italy. One hundred and twenty interviews were conducted with the aim of ascertaining children's knowledge of the 1989 International Convention on the Rights of the Child, collecting their opinions and perceptions on the rights granted, and gathering their normative social representations of the very concept of right. Many questions contained in the interview concerned rights pertaining to various spheres, where children's rights clash with those of adults: a) very personal rights, b) rights relating to everyday life situations, c) rights concerning more

5 William Damon, 'The Development of Justice and Self-interest during Childhood', in Melvin J. Lerner, Sally C. Lerner, The Justice Motive in Social Behavior. Adapting to Times of Scarcity and Change (New York, 1981), 57.

6 Gary Matthews, The Philosophy of Childhood (Cambridge, 1994); Berry Mayall, Towards a Sociology for Childhood. Thinking from Children's Lives (Maidenhead, 2002); Berry Mayall, 'Lo status morale dell'infanzia: appunti dalla Gran Bretagna', in Heinz Hengst, Helga Zehier (eds.), Per una sociologia dell'infanzia (Milano, 2004), 124.

7 Berry Mayall, 'Lo status morale dell'infanzia: appunti dalla Gran Bretagna', in Heinz Hengst, Helga Zehier (eds.), Per una sociologia dell' infanzia (Milano, 2004), 124.

8 Leena Alanen, 'Women's Studies/Childhood Studies. Parallels, Links and Perspectives', in Jan Mason, Toby Fattore (eds.), Children Taken Seriously. In Theory, Policy and Practice (London, 2005); 31; Janet Holland, Rachel Thomson, Sheila Henderson, Sheena McGrellis, Sue Sharpe, 'Catching on, Wising up and Learning from your Mistakes: Young People's Accounts of Moral Development' (2000) 8 The International Journal of Children's Rights 271; Allison James, 'Life Times: Children's Perspectives on Age, Agency and Memory across the Life Course', in Jens Qvortrup (ed.), Studies in Modern Childhood: Society, Agency, Culture (New York, 2005), 248; Jens Qvortrup, 'Varieties of Childhood', in Id. (ed.), Studies in Modern Childhood: Society, Agency, Culture (New York, 2005), 1.

9 The three studies mentioned in this work are part of the following national research programmes: Citizenship Rights of children, Participation and Control (reference n. 9914638391_004, year 1999); Culture, Rights and Normative Socialization of Children and Adolescents (reference n. 200314797_003, year 2003); Mediation in Intercultural Practices, in Managing Conflicts, and in Social Promotion (reference n. 2005145944_003, year 2005). 
difficult decisions, such as children's right to be listened to if their parents decided to separate.

The second research was a study of perceptions of justice among teenagers, conducted in 2003-2004 in two towns in the north of Italy. It involved young people attending the first two classes of four different higher secondary schools with the aim of examining their representations of issues of justice. A total of 29 teenagers were interviewed individually, while 42 were involved in focus groups.

The interviews were conducted through the presentation of scenarios based on questions of justice. Girls and boys were presented with questions that ranged from simpler issues concerning respondents' everyday lives (decisions occurring in the family or among friends), to situations that were not part of their everyday experience and that interviewees were less familiar with (administrative and political decisions, issues concerning human rights violations). The focus groups were presented with a variety of moral dilemmas and the respondents were asked to have joint discussions on them.

Finally, the third study, conducted in 2007, analysed cultural mediation practices with separated children living in residential homes. This research, among other things, aimed at understanding whether the foreign children hosted in those centres were aware of living within multiple normative and legal orders ${ }^{10}$ and whether they had ever come across those conflicts that scholars dealing with mediation, namely cultural mediation, call 'normative conflicts', which occur when individuals have to live with different and often contradictory normative and legal systems. This study was carried out by means of in-depth interviews with 13 separated boys who had been living in reception centres in the north of Italy for at least one year. They came from different countries of strong migratory pressure and were aged between 12 and 18. ${ }^{11}$ Their socialization and integration process had been underway for a relatively long time, under the guidance of social pedagogues and cultural mediators. Research findings focused on separated children's representations of their needs, interests and fundamental rights, as well as the social and legal rules governing their relations with role model adults in their country of origin and in Italy.

\subsubsection{Children's rights to be heard in proceedings concerning parental separation and divorce}

With respect to the first study, children's analytical and moral reasoning skills are interestingly exemplified by the answers they gave about their right to be consulted if their parents decided to separate and their right to express their opinion about their custody.

The interviewees were asked if they should have the right to tell the judge which of their parents they would like to live with if they separate. The question was the following: Chiara's parents are separating; do you think Chiara should have the right to tell the judge which of her parents she would like to live with?

Almost all the respondents, except for five boys and three girls, claimed the right to be heard. Their arguments showed their awareness of the complexity of the situation. Most of them are fully aware that such choice would heavily affect their future life:

10 Boaventura de Sousa Santos, Estado, derecho y luchas sociales (Bogotà, 1991).

11 More precisely: six Moroccans, three Albanians, two Romanians, one Cameroonian and one Pakistani. 
She will be the one who'll have to live with her mother or with her father, so if she prefers one of them she should rightfully say so.

and, at the same time, of the fact that expressing a preference was often taken by the discarded parent as a demonstration of lesser affection:

Maybe she's afraid of losing... of disappointing the other parent

with the risk that

the parent who is not chosen feels 'rejected' and might feel disappointed.

A girl, whose parents had been separated for five years, described her experience noting that it was still difficult for her to take a stand, since one of her parents 'reasons like a child' and took every choice she made to the advantage of the other parent as a lack of affection in his regard. She thus commented on this attitude:

Saying 'I want to stay with this one' is tantamount to saying that you don't love the other one. (...) I still notice that my father reasons like a child, so if I praise mum he'll start saying 'ah, you don't love me then', I mean, he doesn't actually say it but he shows it.

Several responses described the embarrassment or the worry involved when having to choose one parent over the other:

It is difficult to take a stand because you care for both in the same way and yet you have to decide between the two. I would find it embarrassing, because I would probably want to stay with my mother, but at the same time I would feel sorry for my father...

The account given by a now 13-year-old girl illustrates her awareness of the complexity of these questions very well:

Until you are fourteen, you are not allowed by law to tell who you wish to live with (...). As for me, on the contrary, I knew what I wanted very well, maybe not at seven, when my parents separated, but I surely did by the time I was ten. I went to talk to social workers, but I was accompanied by my father or my mother, so I could not speak my mind freely. I didn't say what I would have said if I had been alone. I don't like hurting people. The fact that I want to live with one parent does not mean that I don't love the other one (...). I think that children should be able to express their views, though not decide everything; they should just be able to voice their opinion because if, on the contrary, I should have to decide, I would feel guilty.

Other respondents, like this girl, recognize the difference between the right to express their opinions and the right to decide. They showed to be in favour of the right to express their opinion in a decision-making process affecting them-which the judge should take in due account-but, on the contrary, they were against making the child responsible for the decision. According to them, the decision should be up to the judge, also because he may be aware of some factors that might escape them:

Sure, she must have the right to have her say, but at the end of the day it is up to the judge to assess who she's better off with.

She has to endure difficult family circumstances; choosing the parent she prefers to live with would make it easier for her to go through this situation. However, one would need to check whether the parent she chooses is able to look after her, give her an education and keep her. One needs to assess whether that's feasible...

It is interesting to notice that half of the eight children who were against the recognition of the right to express a preference in order to determine their custody had experienced their parents' separation. They account for about one fourth of all the respondents with separated or divorced parents. It thus appeared that these children 
were less disposed to get the child involved in the proceedings concerning their custody. Three boys and a girl, in the light of their experience, reckoned that expressing their views in this regard would mean compromising their relationship with the noncustodial parent. They also did not feel they were ready to make such decision:

I don't think it would be a good idea, because she would be put against her parents-I know this because my parents are divorced too. I will shortly have to see the judge and tell her that my father doesn't help us financially: it is already quite difficult to say that he never helps us, let alone if I was to say it in front of him...

I think this is a difficult choice that would only complicate things (...). If the child has to choose one of the parents, whom she loves in the same way, the one who is left out... will feel disappointed.

The other four respondents argued that the child, as opposed to the judge, was not able to evaluate the most suitable solution correctly on the grounds of her age:

\subsubsection{For justice's sake}

With respect to the second research, which aimed to show adolescents' moral and legal reasoning, below are some findings from one of the focus groups organized in the framework of a study focused on young people's sense of justice.

The scenario presented was taken from Michael Kohlhaas, a play written by German playwright Heinrich von Kleist in 1810. Von Kleist's work tells about Michael Kohlhaas, a horse dealer who, in order to be allowed to cross the land of a local squire, was forced to leave two wonderfully bred horses as security. When he returned, he found his horses in a terrible state; he then refused to take them back and sued the squire for the damages he had suffered. Appalled at the judge's unfavourable ruling and even more at the loss of his own wife, who had been beaten to death by a Brandenburg's guard when she asked for the Governor's intervention in favour of her husband, Michael became the leader of a gang of rebels. In order to obtain justice, he made allies with the worst bandits, with whom he turned to looting and abuse. Since the judges did not behave as they should have done, he had a right, even a duty, to take justice into his own hands. The trial was re-opened, the court ruled in Kohlhaas's favour, but then he was arrested for his acts of banditry. He obtained justice for the damage he had suffered but, at the same time, he was sentenced to death for having threatened the order of the Empire. Finally, Kohlhaas died, but justice had been done.

The dilemma raised by this story is between the duty to disobey the law when it is not right and, on the other hand, the duty to obey it anyway because it is the law. This can be summed up in one key question: is it right to break a law you deem not right because it is contrary to your moral code? Or, on the contrary, should every law, even the most unjust, be obeyed because it is the law, in the name of a meta-law, a higher principle rooted in the need for political allegiance or social order? ${ }^{32}$

The question of obedience/disobedience to an unjust law has always been at the centre of philosophical debate, which is fuelled by opposing scholarly views on the conflict between moral and positive law from perspectives mostly related to moral and political philosophy and the philosophy of law. To put it very simply: on the one hand, there is the belief that every conflict between moral and positive law should be resolved in favour of the former. The opposing approach, on the contrary, maintains

12 Vincenzo Ferrari, Giustizia e diritti umani. Osservazioni sociologico-giuridiche (Milano, 1995), 101. 
that legality and morality belong to separate spheres; thus, if the conflicts arising between them generate some moral dilemmas, these should not interfere with the general duty to obey the law. Consequently, all laws must be obeyed, even those that are wrong on moral grounds. Nevertheless, at the same time, people have the duty to make all lawful efforts to change these laws. According to this view, therefore, obedience to the law is a moral duty.

Kohlhaas's tragedy is in some ways similar to that of Antigone. Von Kleist's character, just like the main character of Sophocles's tragedy, experiences a profound conflict between two duties grounded in different normative frameworks: on the one hand, the legal system and, on the other hand, moral codes. Here too, we are faced with non-dilemmas. ${ }^{13}$

Just like Antigone, Michael Kohlhaas stimulated much thought among scholars, who have expressed conflicting views. As Thomas Mann remarked, Michael Kohlhaas's story could raise very mixed feelings among readers. On the one hand, it may stir admiration for the determination displayed by the main character, who becomes a hero and a defender of justice. On the other hand, however, the crimes he committed in his 'terror-bound frenzy to improve the world' and seek revenge could also cause horror and disgust. ${ }^{14}$ In particular, Mann noted that Michael Kohlhaas received praise from Rudolf von Jhering who, in his 1872 work The struggle for Law mentioned von Kleist's play and wrote enthusiastically about the ideal feeling of justice held by the main character. For Jhering, standing up for one's rights is an individual's duty not only towards oneself but also towards society. Goethe, in contrast, as Mann remarked, had an opposite view. He defined Kohlhaas as an excessive character and his behaviour as an almost obsessive need to turn a personal matter into an issue of general interest.

Michael Kohlhaas's story also invites another important question. In fact, his fight for the recognition of the violation of his rights may not only serve to redress the injustice he had suffered, but eventually it could also secure justice for his fellow citizens. His struggle would then become of public interest. This is exactly the point Jhering made. He thought that the violation of a person's rights amounted to a violation of 'the Law'. ${ }^{15}$ Within this framework, Kohlhaas is not a man 'obsessively confined in his narrow world of self-interest (...), but rather a staunch defender of the cause of law'16 and justice, which is considered as a moral value that cannot be seen as separate from human dignity. Consequently, defending one's rights means preserving one's moral existence.

Finally, this story begs the question of whether it is fair to sacrifice innocent people in the name of a higher good, which, in this case, is justice.

Our focus group discussions were started with the question: 'How do you judge the behaviour of the main character of this story? Try to put yourselves in his shoes and say what you would have done in his place'.

13 Persio Tincani, 'I dilemmi morali e le scelte tragiche', in Paola Ronfani (ed.), Non è giusto! Dilemmi morali e senso della giustizia nelle rappresentazioni degli adolescenti (Roma, 2007), 43.

14 Thomas Mann, 'Heinrich von Kleist e i suoi racconti', in Id., Nobiltà dello spirito (Milano, 1997), 119.

15 Rudolf von Jhering, 'La lotta per il diritto'[1872], in Roberto Racinaro (ed.), La lotta per il diritto e altri saggi (Milano, 1989), 71.

16 François Chazel, 'Sentiment d'injustice, lutte pour le droit et rationalité axiologique: variations sur le 'cas' de Michail Kohlhaas' (2003) 55 Droit et Société 774. 
Almost all participants thought that Michael Kohlhaas's behaviour was wrong and called him 'stupid', 'naïve', 'crazy', 'fanatic', and 'selfish'. Their reasons drew on family and life values, which should not be sacrificed because of an injustice:

There are other values as well as justice, like the family.

It makes you wonder whether it was worth it. I don't think it was, I wouldn't sacrifice what he sacrificed: he lost everything in the name of a moral principle. Of course, everybody would do it in theory, but if you actually do it in practice you must be mad!

I think he did it all wrong, because, in order to obtain justice, he involved people who had nothing to do with it and then he died too. What use was justice to him in the end?

These opinions confirmed the importance of family in young people's scale of values. This is also shown in other studies, ${ }^{17}$ where family ranks first.

Some participants, however, agreed with the ideal of justice supported by Kohlhaas, although they disapproved of his methods, thus showing their aversion to violence:

I don't agree with Kohlhaas's behaviour although maybe, if I put myself in his shoes, overwhelmed with rage, I would have taken justice into my own hands too. Still, I wouldn't have burned down houses and villages.

I don't agree because those who had their homes burned down suffered an injustice too and if they had behaved the way he did, it would have gone on forever.

The value of non-violence also underlay the criticism expressed by almost all participants when they were asked if it was legitimate to have a violent reaction when a public authority did not acknowledge a violation of legitimate rights and did not provide redress for the wrongs suffered. Placing oneself outside the law and taking justice into one's own hands after suffering an injustice was tolerated, but never through the use of violence:

I don't think it's right to use violence but I think it's right to rebel against injustice.

If we all reacted like that, following our instinct, we wouldn't be civilized people.

Others added that taking justice into one's hands should not involve the use of violence against innocent people:

There is a limit to everything. I mean, I accept the fact that he went and burned Von Tronka's castle to the ground but I do not accept his burning down villages and killing those who lived in them.

But some interviewees thought that

taking justice into one's hands is absolutely wrong because, even if a law is unjust, that's not the way to deal with it.

The general opinion was that the use of violence puts the victim at fault, leading to a spiralling sequence of abuses which it may become hard to get out of:

Then you'd become the bully because you're destroying villages. You'd get down to Von Tronka's level.

Some participants said that it was not worth fighting powerful people, even for a just cause, because in these cases defeat was in the cards. They thought that in the face of a court decision, albeit an unjust one, one should give in if up against very powerful people:

17 Carlo Buzzi, Alessandro Cavalli, Antonio de Lillo (eds.), Rapporto giovani. Sesta indagine dell'Istituto IARD sulla condizione giovanile in Italia (Bologna, 2007). 
Surrendering is wrong but unfortunately that's the way of the world. The just will always pay the price.

If I'd been in his shoes, after the court had ruled against me, I would have just given up.

Among the few who approved of Kohlhaas's behaviour, some of them called him 'heroic' and expressed their admiration for him. They pointed out that he had acted to defend a principle, the principle of justice, for which he had given up a life of comfort, his family and even his own life:

I think that Kohlhaas is to be admired because he had a sense of justice. His behaviour was extreme, that's true, but he pursued his ideal even at the cost of losing his wife and leaving his children. I don't think there would be people ready to do that nowadays.

Michael fought for justice. He lived in the 16th century, when people had to fight for justice. That's why we all have justice now, thanks to these people who fought for a principle.

Several focus group participants, even though they disapproved of Kohlhaas's behaviour, conceded that, if they had been in his shoes, they would have very likely behaved in the same way. In this case too, there was a discrepancy between what was considered as fair and unfair on an abstract level and, on the other hand, judgements expressed on the basis of experience:

I would have done exactly the same thing because suffering an injustice and not seeing it recognized would inevitably make me take justice into my own hands. I wouldn't accept the court's ruling which, in this case, appeared to be in favour of a powerful family.

Maybe, if I were to put myself in Kohlhaas's shoes, overwhelmed with rage, I would have taken justice into my own hands too. Still, I think that's absolutely wrong because, even if a law is unjust, that's not the way to deal with it.

The last question asked whether Michael Kohlhaas, by reclaiming his rights, only received redress for the wrong suffered or whether, on the contrary, he also secured justice for his fellow citizens. A high number of participants, both male and female, were convinced that Kohlhaas's actions would yield positive consequences:

People like Kohlhaas contributed to change the rules and the way we live as people and as a society. Nowadays, these things would be a lot worse if those people hadn't existed.

This story certainly made justice less dependent on power. Michael's rebellion toned down the arrogance of those squires.

On the opposite side, some focus group participants did not believe that actions of people like Kohlhaas helped fight injustice:

I don't think Kohlhaas's conduct secured justice for other citizens too, because he eventually only got justice for himself. The court probably couldn't take it anymore, von Tronka was fed up with the whole thing and so they gave him what he wanted. However, I don't think that those coming after him would get the same treatment, unless they used the same means as him and rebelled like him.

\subsubsection{Separated children's representations of their rights and needs}

The final examples of young people's moral reasoning skills are taken from research that sets itself apart from our previous studies. This is because, in the first place, the sample was not made up of Italian boys but it was composed of young people coming from countries of high migration pressure. Secondly, the sample belonged to a specific category of underage children: separated children, that is children, for the most part teenagers, who migrate to a foreign country by themselves. 
This study admittedly has some limitations, due to the size and the particular nature of the sample, which was made up of separated children who started their settlement and integration process in residential homes. However, we believe this survey is particularly revealing as it focuses on the representations of needs and rights, which have been scarcely dealt with in previous research on separated children. For this reason, we think that this work could provide an interesting contribution to the body of research that has developed in Italy and other European countries since the 1990s with the aim of identifying the social and age composition of separated children as well as the reasons behind their migration choice and their expectations for the future. ${ }^{18}$ These studies are innovative with regard to the traditional research approach, which had focused almost exclusively on the so-called forced migration of children and which portrayed migrant children as 'passive, vulnerable and necessarily exploited' within the migration process, ${ }^{19}$ with no possibilities or ability to make autonomous migration choices. These works, on the contrary, focus on the fact that separated children are usually grands enfants, not only in terms of age but also because almost all of them have reached a high degree of autonomy and sense of responsibility. ${ }^{20}$

In this regard, it should be pointed out that, while in 'rich countries' children's transition to adulthood has become increasingly extended, which entails a later assumption of adult responsibilities and the postponement of full independence, in 'poor countries', on the contrary, 'our' representation of childhood is hardly ever found; in fact, early access to adulthood implies a shorter childhood and no adolescence because poverty forces children to grow up fast and 'erases their rights.' ${ }^{21}$ Moreover, in countries where everyday life is characterized by constant uncertainty due to economic and political instability, there is a different perception of risk compared to affluent countries: emigration is not considered as more difficult or hazardous than one's present life or future perspectives in the country of origin. Therefore, when reading and analysing respondents' narrations, we need to set aside our own representation of childhood, which, on the contrary, is more extended and clearly separated from adulthood, it is often idealized and, for this reason, it is equated exclusively with light-heartedness and carelessness. ${ }^{22}$ Separated children should be approached in a more objective way, giving due consideration to their personal histories, their individual characteristics and their own specific needs.

\footnotetext{
18 See Giovanna Campani, Zoran Lapov, Francesco Carchedi, Le esperienze ignorate. Giovani migranti tra accoglienza, indifferenza, ostilità (Milano, 2002); Monia Giovannetti, Minori stranieri in movimento: percorsi e pratiche tra integrazione e devianza. Quaderni di Cittàsicure 21 (vol. 2) (Bologna, 2000); Dario Melossi, Monia Giovannetti, I nuovi sciuscià. Minori stranieri in Italia (Roma, 2002); Clara Silva, Giovanna Campani, Crescere errando. Minori immigrati non accompagnati (Milano, 2004); Giovanna Campani, Olivia Salimbeni (eds.), La fortezza e i ragazzini. La situazione dei minori stranieri in Europa (Milano, 2006).

19 Caitlin Farrow, 'A Review of European Research Findings on Children in Migration', in Save the Children, Conference Report. Focus on Children in Migration (2007) (<http://www.savethechildren.net/ separated_children/publications/reports $>$ ), 6 .

20 See Irene Azzari, Olivia Salimbeni, 'Il minore straniero non accompagnato. Definizioni e legislazione internazionale', in Giovanna Campani, Olivia Salimbeni (eds.), La fortezza e i ragazzini. La situazione dei minori stranieri in Europa (Milano, 2006), 19.

${ }^{21}$ Giulia Di Bello, 'Prefazione', in Giovanna Campani, Olivia Salimbeni (eds.), La fortezza e i ragazzini. La situazione dei minori stranieri in Europa (Milano, 2006), 10; Vittoria Tola, 'Prefazione', in Giovanna Campani, Zoran Lapov, Francesco Carchedi (eds.), Le esperienze ignorate. Giovani migranti tra accoglienza, indifferenza, ostilità (Milano, 2002), 13.

22 Alan Prout, Allison James (eds.), Constructing and Reconstructing Childhood: Contemporary Issues in the Sociological Study of Childhood (London, 1990).
} 
Within the framework of this study, it is interesting to consider some examples of the reasoning developed by our young interviewees when they were asked to assess the rules regulating access to employment and compulsory education in their country of origin compared to Italy.

First of all, it should be noted that, in our survey, work was the most frequently cited reason for migrating. Our interviewees therefore seemed to consider work as their main need. Children migrating on their own, for the most part, aimed at integrating into Italian society through employment. ${ }^{23}$ Almost all respondents declared they had decided to leave their country to find a way out of poverty and marginalization, a situation which, in their mind, could not be changed. They affirmed they left with a clear plan that had been agreed with their families, sometimes not without a struggle, with the aim of finding a job that could allow them to support themselves and their relatives as soon as possible.

Almost all these young boys, who had grown up before their time compared to 'Western' children, said they attended school irregularly and only for few years, while doing odd jobs or in some cases working every day, with or even without their parents' permission.

The interviewees' words reveal that, in their countries of origin, education is widely underrated: it is not regarded as a value in itself, a fundamental right, a means of emancipation but, on the contrary, it is often seen as preventing children from seizing the already scarce unskilled job opportunities that might arise, where no qualification is required anyway. In this regard, it is particularly revealing to notice that only few interviewees declared they were aware of compulsory education laws in their country of origin while some of them ignored the very existence of compulsory education. Even those who were actually aware of those regulations declared they had often infringed them.

Once they got to Italy and learned that they could not access the labour market without having finished compulsory schooling, they assigned education an instrumental value.

When you were told that you would have gone to live in a residential care home, did you tell them what you would have liked to do?

Yes, I'd really like to find a job but then I understood that without a lower secondary school qualification I couldn't work... so I'd better finish lower secondary school, attend a course and look for a job (16 years old, Albanian).

It should be noted, however, that many respondents found it hard to accept the idea of postponing their access to the labour market—and, most importantly, postpone earning an income-to attend school, thus disappointing their families' as well as their own expectations.

Some respondents claimed their need/right to work, affirming that education was a right they would forgo in favour of their need/duty to support their family. In those cases, the interviewees' current situation led to a rupture between what could be defined as an 'abstract right' (education) and, on the other hand, what was claimed as a 'concrete right' (work). In other words, there was a separation between what these young migrants thought the rights of people their age should be in theory and, on the contrary, what they reported as their concrete needs, on the basis of their social,

23 Joseph Moyersoen, 'I minori stranieri non accompagnati', in Ermenegildo Ciccotti, Enrico Moretti, Roberto Ricciotti (eds.), I numeri italiani. Infanzia e adolescenza in cifre-Edizione 2007 (Firenze, 2007), 89. 
economic and cultural background in their country of origin. This rupture could also be ascribed to the strong sense of responsibility these children felt towards their family: they didn't want to disappoint them nor did they want to fail their expectations.

\section{In Albania, is it normal for young people your age to work?}

I think it would be better to go to school, but... in Albania, many children don't go to school, they'd rather work. When I was there, poor children started working even before the age of eleven. Now, though, I'm told that young children don't take to the streets to work anymore because nobody would hire them. I'm sorry to hear that, because their families need the money (16 years old, Albanian).

It is interesting to note that although some of them thought that it was right for Italian law to allow employment only to children over compulsory school age, at the same time, they were convinced that these provisions should not be introduced in their countries of origin because they would have negative repercussions on the already difficult financial situation of several families.

Under Italian law, children under 15 years of age are not allowed to work. Do you think that's right?

Yes, it is in Italy. In my country, on the contrary, it wouldn't be right because there you need to work at an earlier age and support your family (17 years old, Moroccan).

\subsection{Some final comments}

On the whole, the examples illustrated here show that young people possess the reasoning skills to face even complex questions with regard to situations affecting their everyday life, as well as more complex situations that are far from their experience. The sample showed high competencies and a good ability to use different justice and moral criteria as well as a strong and realistic sense of the complexity of different moral situations.

Boys and girls who participated in our interviews and focus groups displayed a considerable ability to draw on a vast array of rules and moral principles and also normative and legal systems, which they chose in a selective and complementary way according to each given situation.

Especially in focus group discussion, both boys and girls were able to reason and discuss the complex questions presented to them, displaying a good practical knowledge of moral concepts. Moreover, participants seemed to realize that they were confronted with dilemmatic situations and they appeared to be aware that it would have been difficult, if not impossible, to find a satisfactory and fair solution in all levels of judgement: every choice inevitably carries positive and negative consequences, which one needs to take responsibility for.

In particular, they were clearly aware of the existence of two different types of judgement: the legal and the moral. On several occasions, as mentioned above, they pointed out that what was 'legally right' could not always be considered as 'morally right'; it was also observed that, in a moral perspective-where specific values and criteria such as loyalty, trust, kinship, and friendship come into play-different situations would be considered in different ways, whereas, on the contrary, the law should deal with them all in the same way.

In the survey with separated children, respondents showed they were aware of the complexity of their situation; they also appeared to be able to form different 
judgements about laws, needs and rights depending on the context and specific situation. In particular, it was noticed that they were aware of the gap between what the host society expected of them and viewed as a need for them and, on the other hand, what they expected of society and what they thought they needed. Finally, thanks to them, it was also possible to establish that there is often a separation between what respondents reckon the needs of people their age should be on an abstract level and, on the other hand, the actual needs they reported they had in their everyday life, on the basis of their past experience, their culture and the context they lived in. Indeed, the variables relating to the interviewees' 'culture of origin' and the 'culture of their country of settlement' played a key role in shaping their opinions when they were asked to move away from abstract reasoning and express context-specific judgements. 